\title{
ZnO Nanoparticles Treatment Induces Apoptosis by Increasing Intracellular ROS Levels in LTEP-a-2 Cells
}

\author{
Caixia Wang, ${ }^{1,2}$ Xiaoke Hu, ${ }^{1}$ Yan Gao, ${ }^{3}$ and Yinglu $\mathrm{Ji}^{4}$ \\ ${ }^{1}$ Key Laboratory of Coastal Biology and Bioresource Utilization, Yantai Institute of Coastal Zone Research, \\ Chinese Academy of Sciences, 17 Chunhui Road, Laishan District, Yantai 264003, China \\ ${ }^{2}$ University of Chinese Academy of Sciences, Beijing 100049, China \\ ${ }^{3}$ National Oceanographic Center, Qingdao 266071, China \\ ${ }^{4}$ College of Marine Life Science, Ocean University of China, Qingdao 266003, China
}

Correspondence should be addressed to Xiaoke Hu; xkhu@yic.ac.cn

Received 22 May 2014; Accepted 7 November 2014

Academic Editor: Jose Teixeira

Copyright (C) 2015 Caixia Wang et al. This is an open access article distributed under the Creative Commons Attribution License, which permits unrestricted use, distribution, and reproduction in any medium, provided the original work is properly cited.

Owing to the wide use of novel nanoparticles (NPs) such as zinc oxide $(\mathrm{ZnO})$ in all aspects of life, toxicological research on $\mathrm{ZnO} \mathrm{NPs}$ is receiving increasing attention in these days. In this study, the toxicity of $\mathrm{ZnO}$ NPs in a human pulmonary adenocarcinoma cell line LTEP-a-2 was tested in vitro. Log-phase cells were exposed to different levels of ZnO NPs for hours, followed by colorimetric cell viability assay using tetrazolium salt and cell survival rate assay using trypan blue dye. Cell morphological changes were observed by Giemsa staining and light microscopy. Apoptosis was detected by using fluorescence microscopy and caspase-3 activity assay. Both intracellular reactive oxygen species (ROS) and reduced glutathione (GSH) were examined by a microplate-reader method. Results showed that $\mathrm{ZnO} \mathrm{NPs}(\geq 0.01 \mu \mathrm{g} / \mathrm{mL})$ significantly inhibited proliferation $(P<0.05)$ and induced substantial apoptosis in LTEP-a-2 cells after $4 \mathrm{~h}$ of exposure. The intracellular ROS level rose up to 30-40\% corresponding to significant depletion (approximately $70-80 \%)$ in GSH content in LTEP-a-2 cells $(P<0.05)$, suggesting that ZnO NPs induced apoptosis mainly through increased ROS production. This study elucidates the toxicological mechanism of ZnO NPs in human pulmonary adenocarcinoma cells and provides reference data for application of nanomaterials in the environment.

\section{Introduction}

With rapid development of nanotechnology, the application field and commercial manufacturing scale of synthetic nanomaterials and nanoparticles (hereinafter referred to as NPs) have undergone significant expansion worldwide. This situation has increasingly aggravated the damage to ecological environment and human health, mainly because various NPs have diverse effects (small-scale, surface, quantum-size, and/or macroscopic quantum tunneling) [1]. Research of nanomaterial toxicology is presently at an early development stage. Associated research has been conducted on carbon nanomaterials first, and the test objective has been extended from mouse [2] to aquatic organisms (largemouth bass, Daphnia magna, Tetrahymena thermophila, and crucian carp) and human cells [3]. Therefore, the biological safety of NPs has aroused great concerns by governments and academic circles.

Metal oxide nanomaterials such as zinc oxide $(\mathrm{ZnO})$ NPs exhibit antibacterial, anticorrosive, antifungal, and UVfiltering properties as well as certain cytotoxicity [1]. Compared to titanium dioxide $\left(\mathrm{TiO}_{2}\right) \mathrm{NPs}, \mathrm{ZnO}$ NPs exert relatively strong toxic effects on human pulmonary epithelial cells, and the toxicities of both kinds of metal oxide NPs are controlled by their physicochemical characteristics (e.g., size and crystal phase) [3]. Regarding the underlying mechanism of toxicity, $\mathrm{TiO}_{2}$ NPs promote the generation of intracellular reactive oxygen species (ROS) by modulating cell metabolism with light [4], whereas overproduction of ROS may damage the antioxidant mechanism in macrophages [5] and cause toxic effects in brain microglia or other cells $[6,7]$. Similarly, $\mathrm{ZnO}$ NPs may cause oxidative stress in macrophages and 
human cells, resulting in lipid peroxidation, cell membrane damage, and ultimately cell death or apoptosis $[8,9]$. Despite previous research achievements, the toxicological mechanism of ZnO NPs has not been elucidated in certain species or cancer cells. Exploring the exact mechanism of this novel nanomaterial is of great value for clinical trials of cancer treatment.

In the present study, we assessed the in vitro toxicity of $\mathrm{ZnO}$ NPs in a human pulmonary adenocarcinoma cell line, LTEP-a-2. Log-phase cells were exposed to different concentrations of ZnO NPs for hours, followed by in vitro tests of cell viability, survival rate, morphological changes, apoptosis, and intracellular ROS and reduced glutathione (GSH). The results were analyzed to explore the toxicological mechanism of $\mathrm{ZnO}$ NPs in LTEP-a-2 cells, further laying a foundation for in-depth toxicological study and clinical trials of this nanomaterial for cancer treatment.

\section{Materials and Methods}

2.1. $\mathrm{ZnO} N P s$. All experiments were carried out on an ultraclean bench to prevent interference of external factors. Highly purified (99.9\%) ZnO NPs were purchased from Sigma Aldrich (St. Louis, USA). Stock solutions of $\mathrm{ZnO}$ NPs were prepared in Dulbecco's modified Eagle's medium (DMEM) containing $50 \mu \mathrm{g} / \mathrm{mL}$ fetal bovine serum (FBS). To avoid particle aggregation, the prepared solutions were sonicated three times $(20 \mathrm{~s} /$ time $)$ prior to use $[10,11]$. $\mathrm{ZnO}$ NPs in DMEM were characterized in terms of morphology, diameter, tendency of aggregation, and intracellular distribution using a scanning electron microscope (SEM, Hitachi S4800, Japan). Zeta potential analysis of ZnO NPs in DMEM was performed by using dynamic light scattering (Malvern Zetasizer ZS9, Worcestershire, UK).

2.2. Cell Culture. Human pulmonary adenocarcinoma cells LTEP-a-2 were obtained from China Center for Type Culture Collection (Wuhan, China) and maintained in DMEM cell culture medium (Gibco, Grand Island, NY, USA) supplemented with $10 \%$ FBS, $100 \mathrm{U} / \mathrm{mL}$ penicillin, and $100 \mu \mathrm{g} / \mathrm{mL}$ streptomycin $\left(37^{\circ} \mathrm{C}, 5 \% \mathrm{CO}_{2}\right)$. For each of the following tests, an aliquot of log-phase culture broth was taken and diluted to obtain the density of $10^{5}-10^{6}$ cells $/ \mathrm{mL}$.

2.3. Cell Viability Assay. The viability of LTEP-a-2 cells was assayed by using the 3-(4,5-dimethylthiazol-2-yl)-2,5diphenyltetrazoliumbromide (MTT) method [12]. Log-phase cells were harvested and thoroughly washed with phosphatebuffered saline (PBS) and then inoculated into 96-well plates (Nunc, Roskilde, Denmark). When the cell density reached approximately $5 \times 10^{4}$ cells/well, different concentrations of $\mathrm{ZnO}$ NPs (0, control; 0.01, 0.25, 0.5, 1.0 , and $1.5 \mu \mathrm{g} / \mathrm{mL}$ ) were added into triplicate wells for 4, 8, 12, and $24 \mathrm{~h}$ of exposure. After aspirated incubation, a medium containing $20 \mu \mathrm{L}$ of $5 \mathrm{mg} / \mathrm{mL}$ MTT was added and the culture was continuously incubated. Four hours later, blue formazan crystal appeared at the bottom of wells, which was then dissolved with $150 \mu \mathrm{L}$ dimethyl sulfoxide. Cell viability was detected by measuring the absorbance of cell culture broth at $490 \mathrm{~nm}$ using a microplate reader (Thermo Varioskan Flash 3001, USA).

2.4. Trypan Blue Exclusion Test. The lethality of $\mathrm{ZnO}$ NPs on LTEP-a-2 cells was assessed by the trypan blue exclusion test [13]. Cells were seeded in 6-well plates with different concentrations of $\mathrm{ZnO}$ NPs (0, control; 0.05, 0.1, 0.2, 1.0, and $5.0 \mu \mathrm{g} / \mathrm{mL}$ ) for $12 \mathrm{~h}$ of exposure in a humidified incubator $\left(5 \% \mathrm{CO}_{2}, 37^{\circ} \mathrm{C}\right)$. Thereafter, cells were trypsinized and resuspended in equal volumes of culture medium and trypan. Viable (unstained) and nonviable (blue-stained) cells were counted using a haemocytometer to calculate the total numbers of living and dead cells.

2.5. Morphological Assay. LTEP-a-2 cells were cultured in 6-well plates with different concentrations of $\mathrm{ZnO}$ NPs ( 0 , control; $0.01,0.05,0.1,0.2$, and $0.5 \mu \mathrm{g} / \mathrm{mL}$ ) for $4 \mathrm{~h}$ of exposure and then fixed with methanol and dried. The cells were stained for 20 min with Giemsa staining solution, rinsed in deionized water, air-dried, and examined under an optical microscope (SH-60, Olympus, Japan) equipped with a digital camera [14]. The stained cells were examined in terms of size, regularity of the margin, and morphological characteristics of the nucleus.

2.6. Apoptosis Detection. ZnO NPs-induced apoptosis after $4 \mathrm{~h}$ of exposure was detected by acridine orange/ethidium bromide $(\mathrm{AO} / \mathrm{EB})$ double staining. Cells were stained with $100 \mu \mathrm{g} / \mathrm{mL} \mathrm{AO} / \mathrm{EB}$ (Sigma, USA) for $2 \mathrm{~min}$, followed by examination using a fluorescence microscope (Leica DM 5000B, Leica Microsystems, Germany). The detection criterion is that normal cells present uniform green nuclei, and late apoptotic cells present orange to red nuclei with condensed or fragmented chromatin $[15,16]$.

2.7. Caspase Activity Assay. Caspase activity was assayed according to the method of Vyas et al. [17]. Cells were cultured in 96-well plates with indicated concentrations of $\mathrm{ZnO}$ NPs for $4 \mathrm{~h}$ and then harvested by centrifugation at $1000 \times \mathrm{g}$ for $10 \mathrm{~min}$. The activity of caspase- 3 was detected by using a colorimetric assay kit (Nanjing Jiancheng Bioengineering Institute, Nanjing, China). Cells were washed with PBS and resuspended in five volumes of lysis buffer $(20 \mathrm{mmol} / \mathrm{L}$ Hepes, pH 7.9; 20\% Glycerol; $200 \mathrm{mmol} / \mathrm{L} \mathrm{KCl;} 0.5 \mathrm{mmol} / \mathrm{L}$ EDTA; $0.5 \% \mathrm{NP} 40 ; 0.5 \mathrm{mmol} / \mathrm{L}$ DTT; and $1 \%$ protease inhibitor cocktail). The content of protein was measured by using the Bradford method, and the absorption of cell culture broth at $405 \mathrm{~nm}$ was measured using a microplate reader (Infinite M200, Tecan, Switzerland) [18]. All treatments were performed in triplicate.

2.8. Intracellular ROS Assay. The intracellular ROS level was measured by active oxygen detection [19-21]. H2DCFDA was deacetylated intracellularly by using a nonspecific esterase and then oxidized by cellular peroxides, yielding a fluorescent compound, 2,7-dichlorofluorescein (DCF, $\lambda \mathrm{EX} / \lambda \mathrm{EM}=$ $485 \mathrm{~nm} / 535 \mathrm{~nm}$ ). Cells were treated with indicated concentrations of $\mathrm{ZnO} \mathrm{NPs}$ (0, control; 0.01, 0.05, 0.5, 1.0, and 


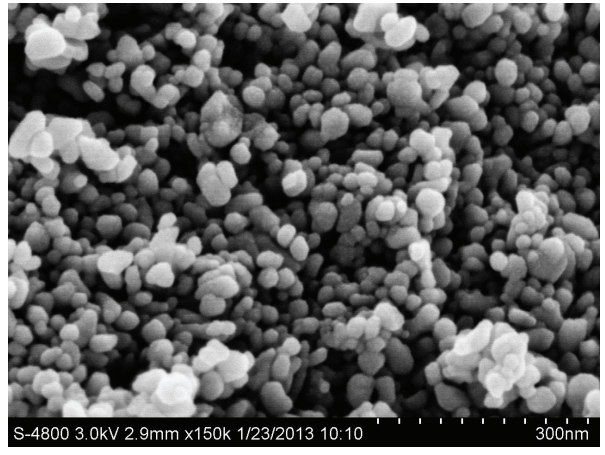

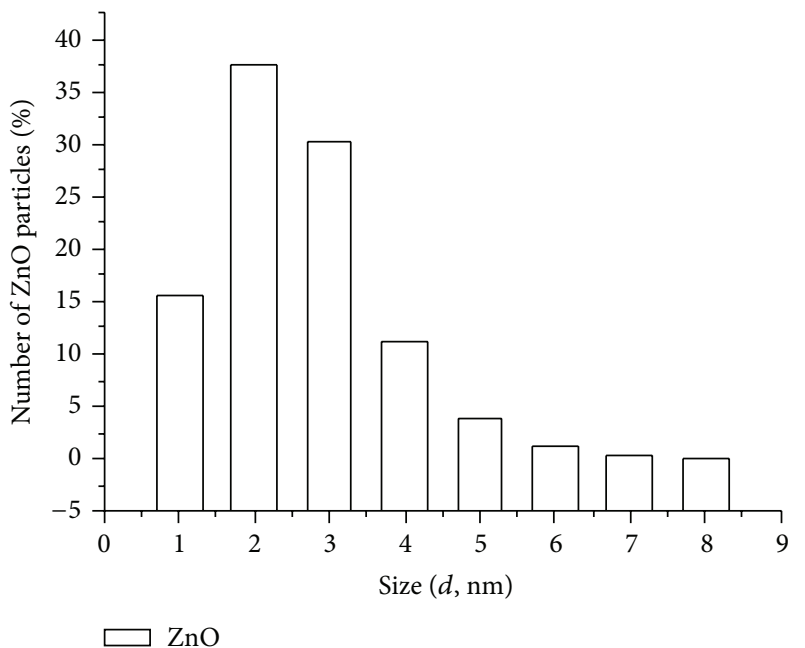

(b)

\begin{tabular}{cccccccc}
\hline Nanoparticles & $\begin{array}{c}\text { Chemical } \\
\text { composition }\end{array}$ & Source & $\begin{array}{c}\text { Diameter } \\
(\mathrm{nm})\end{array}$ & $\begin{array}{c}\text { Density } \\
(\mathrm{g} / \mathrm{mL})\end{array}$ & $\mathrm{pH}$ & $\begin{array}{c}\text { Zeta } \\
\text { potential } \\
(\mathrm{mV})(\mathrm{DI}) \\
\text { water })\end{array}$ & $\begin{array}{c}\text { Average } \\
\text { in DLS } \\
(\mathrm{nm})\end{array}$ \\
\hline $\mathrm{ZnO}$ & $\mathrm{Zn}, \mathrm{O}$ & $\begin{array}{c}\text { Sigma } \\
\text { Aldrich }\end{array}$ & $<100$ & $1.7 \pm 0.1$ & $7 \pm 0.1$ & -18.6 & $<35$ \\
\hline
\end{tabular}

(c)

Figure 1: Major characteristics of $\mathrm{ZnO}$ nanoparticles used in this study. (a) Scanning electron micrograph, (b) size distribution, and (c) major physical properties.

$1.5 \mu \mathrm{g} / \mathrm{mL}$ ) for $4 \mathrm{~h}$ and then washed with PBS and incubated in $30 \mu \mathrm{mol} / \mathrm{L} \mathrm{H}_{2} \mathrm{DCFDA}$ at $37^{\circ} \mathrm{C}$ for $30 \mathrm{~min}$. The content of DCF was detected by using a microplate reader (Varioskan Flash 3001, Thermo, USA). Each group was maintained with the same number of cells in triplicate.

2.9. Intracellular GSH Content Assay. The intracellular GSH content was determined by using a microplate-reader method with a commercial kit (Nanjing Jiancheng Bioengineering Institute, Nanjing, China). LTEP-a-2 cells were inoculated into 6 -well plates at $10^{6}$ cells/well and then exposed to different concentrations of $\mathrm{ZnO} \mathrm{NPs}$ (0, control; 0.01, 0.05, and $0.25 \mu \mathrm{g} / \mathrm{mL}$ ) for $4 \mathrm{~h}$. Cells were then harvested and washed with PBS. The content of GSH was assayed by measuring the absorbance of cell extract at $412 \mathrm{~nm}$ using a microplate reader, calculated according to a standard curve, and normalized by the protein concentration detected using the Bradford method (Sangon, Shanghai, China) [22].

2.10. Statistical Analysis. All experimental data are presented as means \pm standard error of the mean from at least three independent experiments. Data comparison between treatments was accomplished by one-way analysis of variance and Student's $t$-test $(P<0.05$ considered statistically significant).
Statistical analysis was performed in SPSS16.0 (SPSS Inc., USA) and Origin 6.0 (OriginLab Corp., USA).

\section{Results and Discussion}

3.1. Characteristics of $\mathrm{ZnO} N P s$. A description of the morphology and physicochemical properties of $\mathrm{ZnO}$ NPs is regarded as a comparative study in the field of cytotoxicity research $[23,24]$. In the present study, SEM image shows that the ZnO NPs in use are mainly anxiolytic shaped and are partially rhombic (Figure 1(a)). Mean grain diameter of the $\mathrm{ZnO}$ NPs is $30 \pm 5 \mathrm{~nm}$, which matches the supplier's declaration. Zeta potential data indicate that the ZnO NPs have a positive surface charge, $-18.6 \mathrm{mV}$ at $\mathrm{pH} 7.4$ in DMEM (Figure 1(b)), which is inadequate to stabilize the suspension of $\mathrm{ZnO}$ NPs via repulsive force and thus may cause NPs aggregation in DMEM. The size distribution of $\mathrm{ZnO}$ NPs in DMEM, as determined by dynamic light scattering, shows great variations (Figure 1(c)).

3.2. Cytotoxicity of $\mathrm{ZnO}$ NPs. The cytotoxicity of $\mathrm{ZnO}$ NPs in LTEP-a-2 cells was tested by MTT assay using a protocol adopted from previously published reports and manufacturer's instructions $[9,25,26]$, expressed as the percentage 


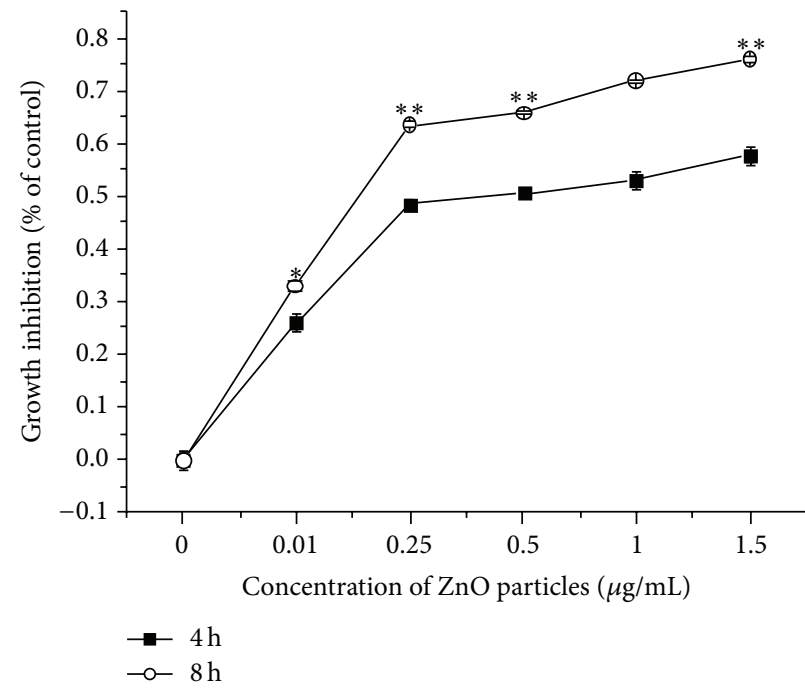

(a)

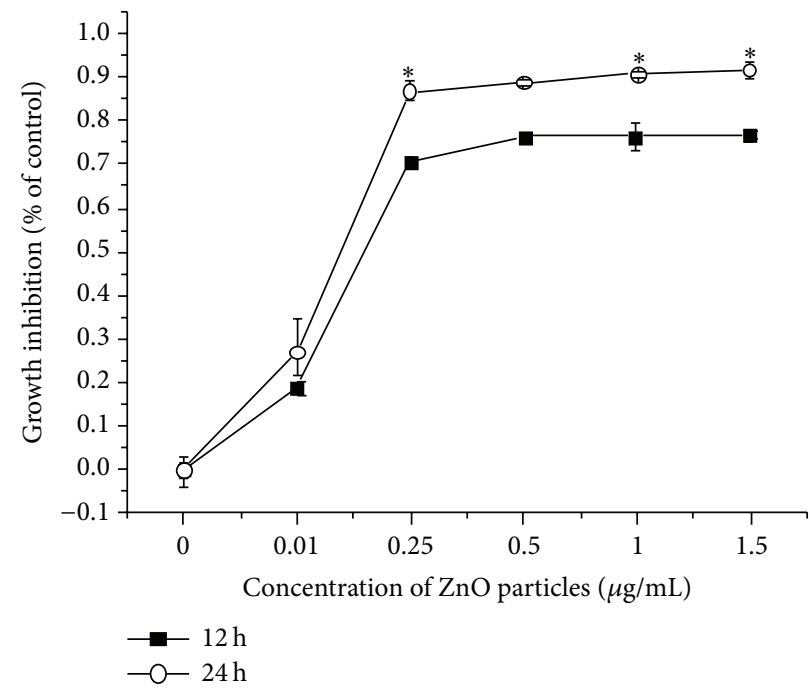

(b)

FIGURE 2: Relative viability of LTEP-a-2 cells after 4-24 h of exposure to different concentrations of $\mathrm{ZnO}$ nanoparticles $(0 \mu \mathrm{g} / \mathrm{mL}$, control). (a) 4 and $8 \mathrm{~h}$ and (b) 12 and $24 \mathrm{~h}$. * versus control, $P<0.05$; * versus control, $P<0.01$ by Student's $t$-test.

of cell mortality relative to the control treatment (Figure 2). After $4-24 \mathrm{~h}$ of exposure to ZnO NPs $(0.01-1.5 \mu \mathrm{g} / \mathrm{mL})$, cell viability declined substantially in a concentration- and timedependent manner; the declines were especially significant after $8 \mathrm{~h}$ of exposure to $\mathrm{ZnO} \mathrm{NPs} \geq 0.25 \mu \mathrm{g} / \mathrm{mL}$ ( $P<$ $0.05)$. The number of cell deaths among all these doses has been nearly $20 \%$ higher than the lower doses over the past $24 \mathrm{~h}$. High cytotoxicity can be observed in cells treated with $\mathrm{ZnO}$ NPs when compared to control group. These results indicate that cell proliferation was inhibited significantly with increasing concentration of $\mathrm{ZnO}$ NPs.

3.3. ZnO NPs Reduced Cell Survival Rate. The dye exclusion test was used to determine the number of viable cells present in a cell suspension. This method is based on the principle that live cells possess intact cell membranes that exclude certain dyes, such as trypan blue, eosin, or propidium, whereas dead cells do not [27]. In this test, a cell suspension was simply mixed with dye and then visually examined to determine whether cells take up or exclude dye. A viable cell was identified with a clear cytoplasm and a nonviable cell with a blue cytoplasm. Results showed that after $12 \mathrm{~h}$ of exposure to $\mathrm{ZnO} \mathrm{NPs}(0.05-5.0 \mu \mathrm{g} / \mathrm{mL})$, the survival rate of LTEP-a-2 cells underwent substantial decreases in a concentrate-dependent manner (Figure 3 ). In the presence of low concentration of $\mathrm{ZnO}$ NPs $(0.05 \mu \mathrm{g} / \mathrm{mL})$, cell survival rate remained above $60 \%$, showing a nearly $40 \%$ decrease relative to the control treatment; as the concentration of $\mathrm{ZnO}$ NPs was increased to $0.1 \mu \mathrm{g} / \mathrm{mL}$, cell survival rate underwent another $40 \%$ decrease, down to approximately $20 \%$ only. Together, these results confirm that the presence of ZnO NPs significantly affected cell survival even at low concentrations (e.g., $0.05-0.1 \mu \mathrm{g} / \mathrm{mL}$ ).

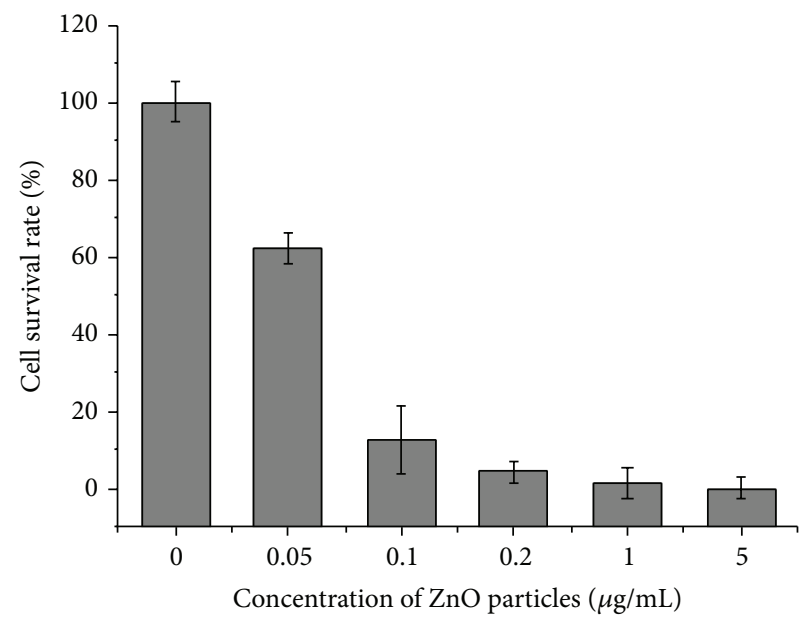

FIGURE 3: The survival rate of LTEP-a-2 cells detected by trypan blue exclusion test after $12 \mathrm{~h}$ of exposure to different concentrations of $\mathrm{ZnO}$ nanoparticles $(0 \mu \mathrm{g} / \mathrm{mL}$, control).

3.4. ZnO NPs Induced Morphological Changes. Giemsa staining is commonly used for identifying morphological changes of monocytes/macrophages in cell preparation [28]. In the present study, Giesma staining was used to examine $\mathrm{ZnO}$ NPs-induced morphological changes in LTEP-a-2 cells for further characterizing the cytotoxicity of this nanomaterial. Microscopic examinations revealed that Giemsa-stained control cells $(0 \mu \mathrm{g} / \mathrm{mL} \mathrm{ZnO} \mathrm{NPs})$ predominantly had round regular cell margins and large nuclei (Figure 4); that is, the control cells were associated with rapid DNA synthesis and fast proliferation. With increasing concentrations of $\mathrm{ZnO}$ NPs $(0.05,0.1$, and $0.5 \mu \mathrm{g} / \mathrm{mL})$, there were evident increases 


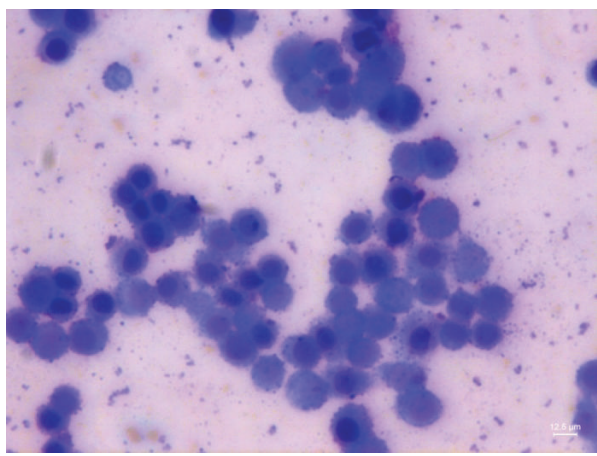

$0 \mu \mathrm{g} / \mathrm{mL}$

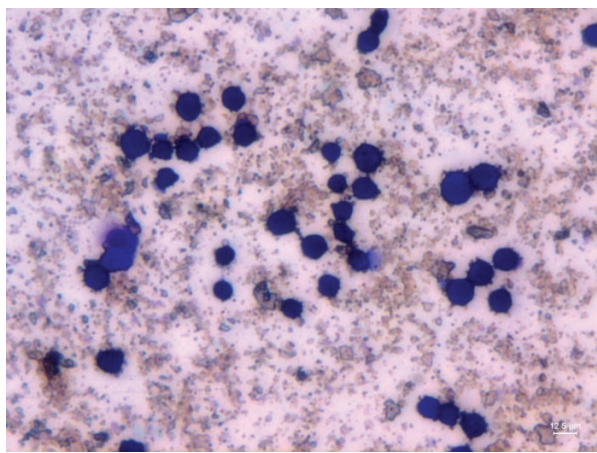

$0.1 \mu \mathrm{g} / \mathrm{mL}$

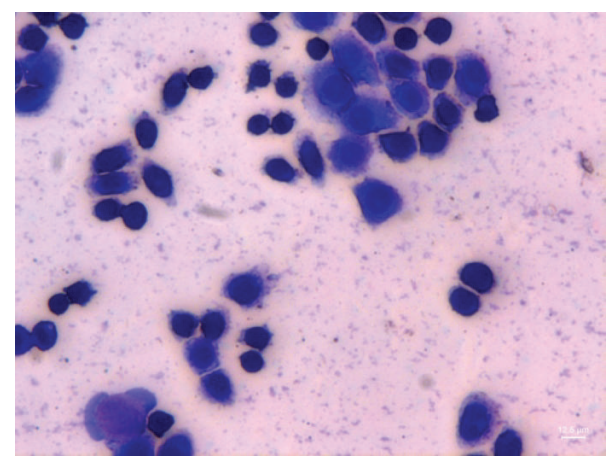

$0.05 \mu \mathrm{g} / \mathrm{mL}$

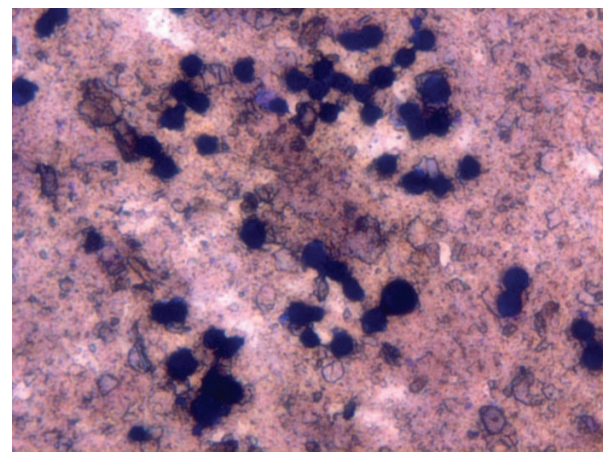

$0.5 \mu \mathrm{g} / \mathrm{mL}$

FIGURE 4: ZnO nanoparticles-induced morphological changes in LTEP-a-2 cells examined by Giemsa staining. Note significant changes in cells after $4 \mathrm{~h}$ of exposure to $\mathrm{ZnO} \mathrm{NPs}(0 \mu \mathrm{g} / \mathrm{mL}$, control).

in the number of pyknotic shrinking cells following a dosedependent manner (Figure 4); the increasing morphological changes in the presence of $\mathrm{ZnO}$ NPs coincided well with the declines in cell survival rate (Figure 3); thus they were associated with proliferation inhibition and/or cell death.

3.5. ZnO NPs Induced Apoptosis. AO/EB staining is considered an ideal method for distinguishing apoptotic cells from necrotic ones $[29,30]$. Here we use AO/EB staining to verify whether ZnO NPs inhibit proliferation of LTEP-a-2 cells by inducing apoptosis or killing cells directly (necrosis). During morphologic examinations, normal viable LTEP-a2 control cells were stained green $(0 \mu \mathrm{g} / \mathrm{mL} \mathrm{ZnO} \mathrm{NPs})$, and the apoptotic cells exposed to ZnO NPs $(0.05,0.1$, and $0.2 \mu \mathrm{g} / \mathrm{mL}$ ) appeared as bright green arcs in an early stage and with condensed, yellow/orange nuclei in the late stage (Figure 5(a)). Additionally, the results of caspase-3 activity assay showed that exposure of $\mathrm{ZnO}$ NPs induced significant increases in caspase- 3 activity compared to the control treatment $(P<0.05$ for $0.01-0.05 \mu \mathrm{g} / \mathrm{mL} \mathrm{ZnO}$ NPs, $P<0.01$ for $0.1-0.5 \mu \mathrm{g} / \mathrm{L} \mathrm{ZnO} \mathrm{NPs;} \mathrm{Figure} \mathrm{5(b)).} \mathrm{As} \mathrm{a} \mathrm{key}$ mediator, caspase-3 plays a pivotal role in caspase-dependent apoptosis [31]. Together, these results confirm that exposure of ZnO NPs induced substantial apoptosis in LTEP-a-2 cells even at low concentrations (e.g., $0.01 \mu \mathrm{g} / \mathrm{mL}$ ), thus inhibiting cell proliferation.
3.6. $\mathrm{ZnO} N P$ s Increased Intracellular ROS. Oxidative stress is considered one of the causative factors of apoptosis in pathogenesis and aggressiveness of most cancers [32]. A moderate rise in ROS level often induces cell proliferation whereas excessive amounts of ROS induce apoptosis [33]. To clarify the mechanism through which ZnO NPs induce apoptosis in LTEP-a-2 cells, we determined the intracellular ROS level by measuring the oxidation of nonfluorescent DCFH-DA to its highly fluorescent derivative DCF. Results showed that ZnO NPs stimulated ROS formation in cells following a concentration-dependent manner (Figure 6(a)). Under a fluorescence microscope, strong green fluorescence was observed in LTEP-a- 2 control cells, whereas blue fluorescence was observed in cells after exposure to ZnO NPs. With increasing concentrations of $\mathrm{ZnO} \mathrm{NPs}$, the blue fluorescence was greatly strengthened accompanied by the appearance of apoptosis vesicles (Figure 6(b)). Together, these results demonstrate that ZnO NPs induce apoptosis in LTEP-a-2 cells through increased production of ROS, consistent with previous findings in macrophages and human liver cells $[8,9]$, as well as in vivo and in vitro tests of a wide range of NPs species $[34,35]$.

3.7. ZnO NPs Decreased Intracellular GSH Content. GSH is one of the most abundant intracellular antioxidant thiols, which is involved in cell redox homeostasis and is central 


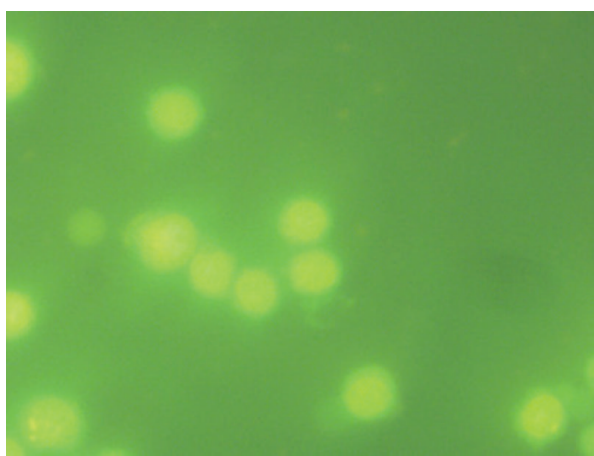

(A)

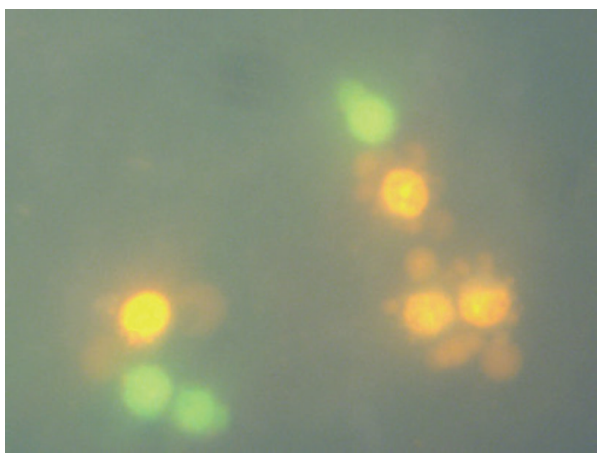

(C)

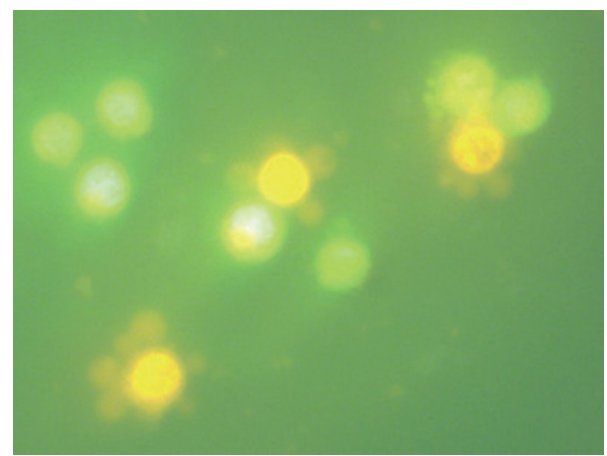

(B)

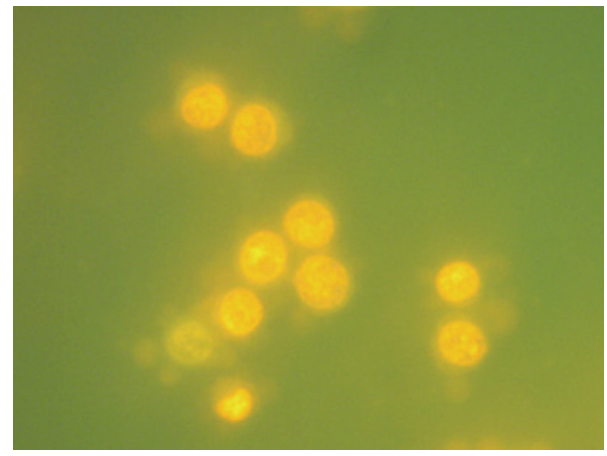

(D)

(a)

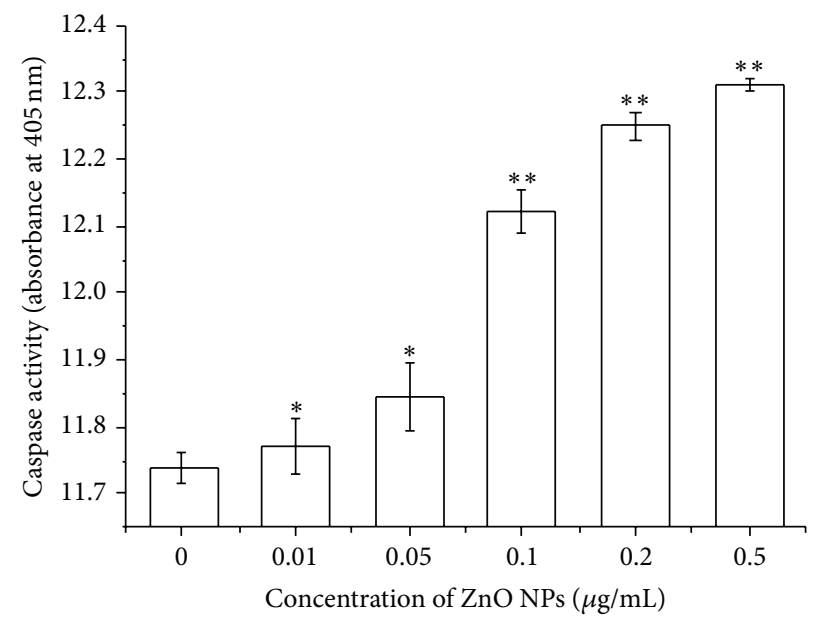

(b)

Figure 5: ZnO nanoparticles-induced apoptosis in LTEP-a-2 cells after $4 \mathrm{~h}$ of exposure. (a) Morphologic examination of LTEP-a-2 cells by AO/EB fluorescence staining ((A) $0 \mu \mathrm{g} / \mathrm{mL}$, control, (B) $0.05 \mu \mathrm{g} / \mathrm{mL},(C) 0.1 \mu \mathrm{g} / \mathrm{mL}$, and (D) $0.2 \mu \mathrm{g} / \mathrm{mL}$ ) and (b) caspase- 3 activity. * versus control, $P<0.05 ; * *$ versus control, $P<0.01$ by Student's $t$-test.

to defensive mechanisms against toxic agents and oxidantmediated injury $[36,37]$. In the present study, the GSH content significantly declined in LTEP-a-2 cells exposed to $\mathrm{ZnO}$ NPs $(0.01-0.25 \mu \mathrm{g} / \mathrm{mL})$ for $4 \mathrm{~h}$ compared with the control cells $(P<0.05$, Figure 7$)$. The depletion of GSH coincided with the enlarging tendency of intracellular ROS level (Figure 6) once again demonstrating that ZnO NPs damaged the antioxidant mechanism of LTEP-a-2 cells.

\section{Conclusions}

In recent decades, nanomedicine has attracted considerable attention in the field of medicine [38-41]. Despite the advantages of nanotechnology, appropriate security measures should be taken to prevent potential hazardous effects of NPs. In the present study, in vitro test results show that $\mathrm{ZnO}$ NPs imposed distinct toxic effect on LTEP-a-2 cells, and 


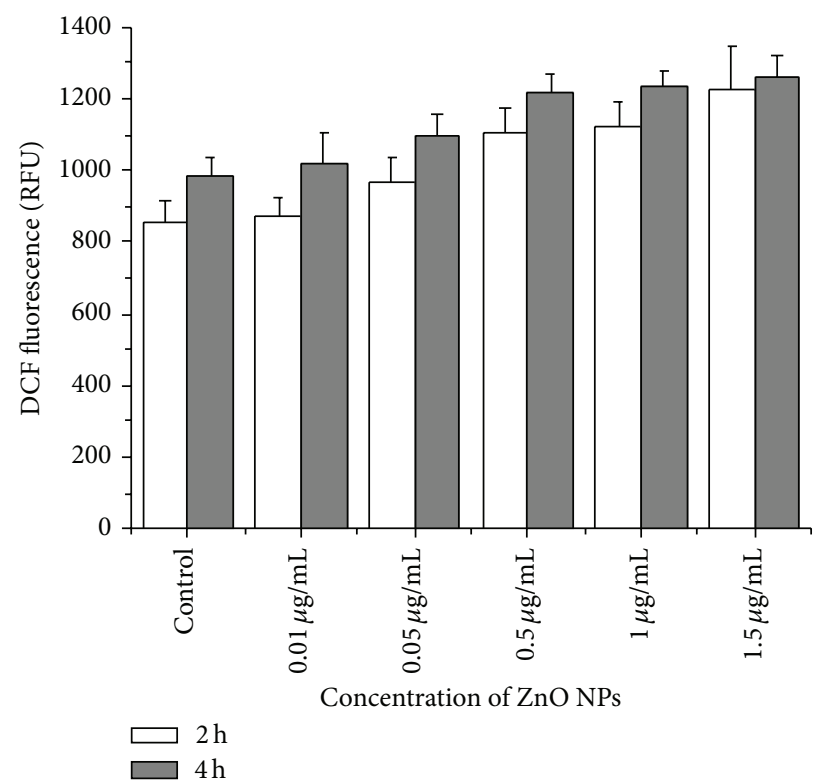

(a)

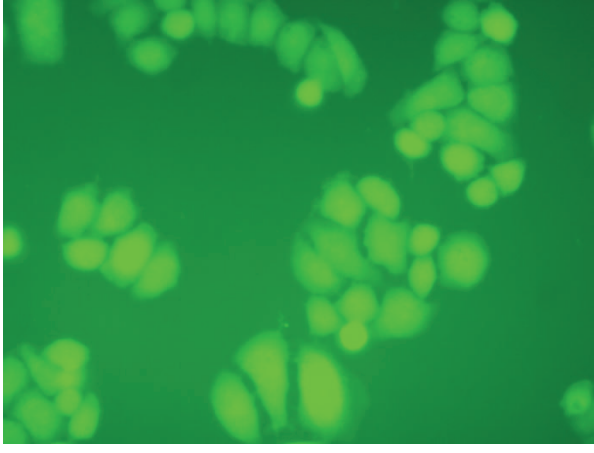

$0 \mu \mathrm{g} / \mathrm{mL}$

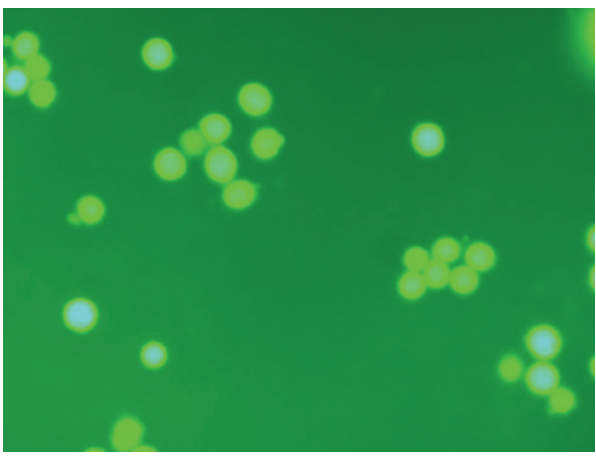

$0.1 \mu \mathrm{g} / \mathrm{mL}$

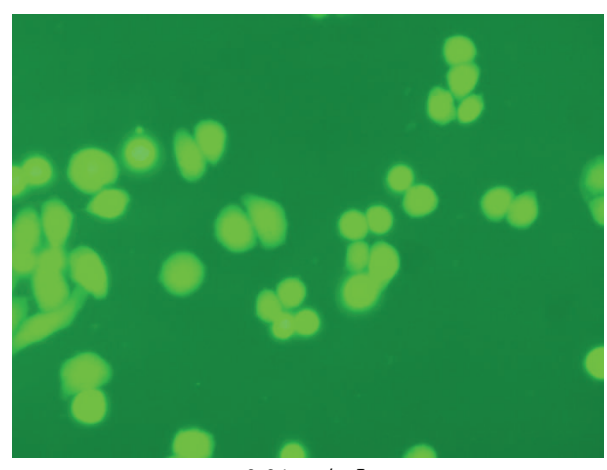

$0.01 \mu \mathrm{g} / \mathrm{mL}$

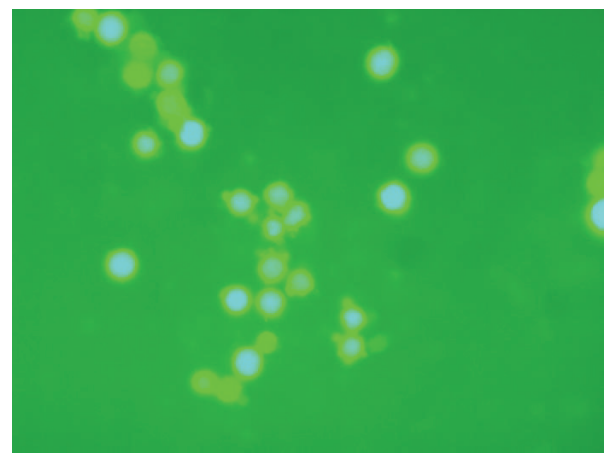

$0.5 \mu \mathrm{g} / \mathrm{mL}$

(b)

FIGURE 6: Increased production of intracellular reactive oxygen species (ROS) in LTEP-a-2 cells after $4 \mathrm{~h}$ of exposure to ZnO nanoparticles. (a) ROS level determined via spectrophotometry and (b) fluorescence intensity measured by microscopy.

the declines in cell viability and survival rate coincided with specific morphological changes and the occurrence of apoptosis. Further exploration of the toxicological mechanism revealed that the increase in ROS coincided with depletion of GSH in apoptotic cells, suggesting that oxidative stress may be the primary toxicological mechanism of $\mathrm{ZnO}$ NPs in
LTEP-a-2 cells. As a common mechanism for NPs-induced cell oxidative damage, increased ROS generation has been confirmed by in vivo and in vitro tests of a wide range of NPs species. Oxidative stress often leads to cell death, by either apoptosis signaling pathways or necrosis signaling pathways depending on its extent of severity. With increasing 


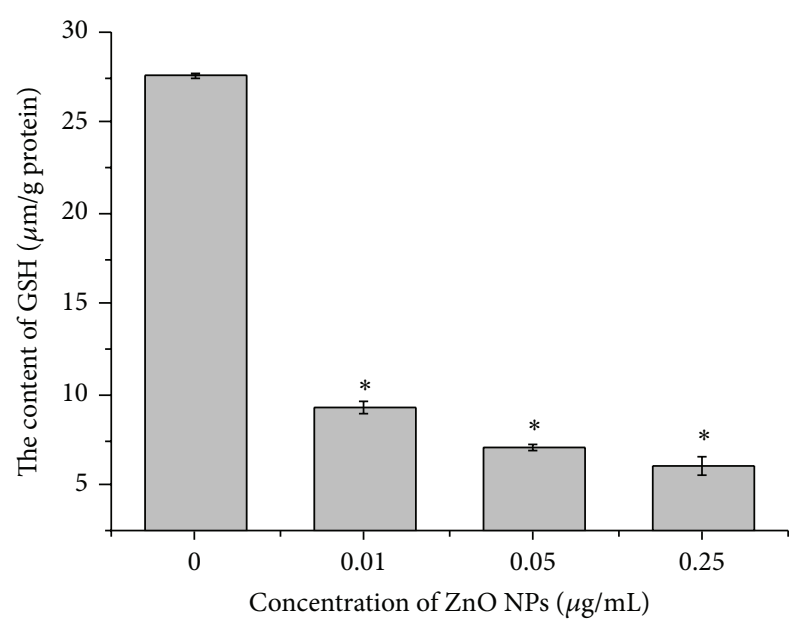

FIgUre 7: Depletion of intracellular glutathione (GSH) in LTEP-a-2 cells after $4 \mathrm{~h}$ of exposure to $\mathrm{ZnO}$ nanoparticles $(0 \mu \mathrm{g} / \mathrm{mL}$, control). GSH content determined by spectrophotometry. ${ }^{*} P<0.05,{ }^{* *} P<$ 0.01 versus control by Student's $t$-test.

evidence for the toxicity of NPs, it is important to plan out precautionary measures and to prevent human exposures to NPs.

\section{Conflict of Interests}

The authors declare that there is no conflict of interests regarding the publication of this paper.

\section{Acknowledgments}

Funding for this research was provided by the Hundred Talents Program of Chinese Academy of Sciences and the Yantai Municipal Science and Technology Project of Shandong Province, China (Grant no. 2012017).

\section{References}

[1] R. F. Service, "Nanomaterials show signs of toxicity," Science, vol. 300, no. 5617, p. 243, 2003.

[2] C.-W. Lam, J. T. James, R. McCluskey, and R. L. Hunter, "Pulmonary toxicity of single-wall carbon nanotubes in mice 7 and 90 days after intractracheal instillation," Toxicological Sciences, vol. 77, no. 1, pp. 126-134, 2004.

[3] I.-L. Hsiao and Y.-J. Huang, "Effects of various physicochemical characteristics on the toxicities of $\mathrm{ZnO}$ and $\mathrm{TiO}_{2}$ nanoparticles toward human lung epithelial cells," Science of the Total Environment, vol. 409, no. 7, pp. 1219-1228, 2011.

[4] J. Jiang, G. Oberdörster, A. Elder, R. Gelein, P. Mercer, and P. Biswas, "Does nanoparticle activity depend upon size and crystal phase?” Nanotoxicology, vol. 2, no. 1, pp. 33-42, 2008.

[5] D. M. Brown, K. Donaldson, P. J. Borm et al., "Calcium and ROS-mediated activation of transcription factors and TNF- $\alpha$ cytokine gene expression in macrophages exposed to ultrafine particles," American Journal of Physiology-Lung Cellular and Molecular Physiology, vol. 286, no. 2, pp. L344-L353, 2004.
[6] T. C. Long, N. Saleh, R. D. Tilton, G. V. Lowry, and B. Veronesi, "Titanium dioxide (P25) produces reactive oxygen species in immortalized brain microglia (BV2): implications for nanoparticle neurotoxicity," Environmental Science and Technology, vol. 40, no. 14, pp. 4346-4352, 2006.

[7] A. Nel, T. Xia, L. Mädler, and N. Li, “Toxic potential of materials at the nanolevel," Science, vol. 311, no. 5761, pp. 622-627, 2006.

[8] V. Wilhelmi, U. Fischer, H. Weighardt et al., "Zinc oxide nanoparticles induce necrosis and apoptosis in macrophages in a p47phox- and Nrf2-independent manner," PLoS ONE, vol. 8, no. 6, Article ID e65704, 2013.

[9] V. Sharma, D. Anderson, and A. Dhawan, "Zinc oxide nanoparticles induce oxidative DNA damage and ROS-triggered mitochondria mediated apoptosis in human liver cells (HepG2)," Apoptosis, vol. 17, no. 8, pp. 852-870, 2012.

[10] C. García-Gómez, M. D. Fernández, and M. Babin, "Ecotoxicological evaluation of sewage sludge contaminated with zinc oxide nanoparticles," Archives of Environmental Contamination and Toxicology, vol. 67, no. 4, pp. 494-506, 2014.

[11] C. M. Sayes, K. L. Reed, D. B. Warheit et al., "Assessing toxicity of fine and nanoparticles: comparing in vitro measurements to in vivo pulmonarytoxicity profiles," Toxicological Sciences, vol. 97, no. 1, pp. 163-180, 2007.

[12] T. Mosmann, "Rapid colorimetric assay for cellular growth and survival: application to proliferation and cytotoxicity assays," Journal of Immunological Methods, vol. 65, no. 1-2, pp. 55-63, 1983.

[13] J. Li, C.-Y. Huang, R.-L. Zheng, K.-R. Cui, and J.-F. Li, "Hydrogen peroxide induces apoptosis in human hepatoma cells and alters cell redox status," Cell Biology International, vol. 24, no. 1, pp. 9-23, 2000.

[14] D. S. Kim, S. H. Kim, J. H. Song, Y.-T. Chang, S. Y. Hwang, and T. S. Kim, "Enhancing effects of ceramide derivatives on 1,25dihydroxyvitamin $\mathrm{D}_{3}$-induced differentiation of human HL-60 leukemia cells," Life Sciences, vol. 81, no. 25-26, pp. 1638-1644, 2007.

[15] D. L. Pitrak, H. C. Tsai, K. M. Mullane, S. H. Sutton, and P. Stevens, "Accelerated neutrophil apoptosis in the acquired immunodeficiency syndrome," The Journal of Clinical Investigation, vol. 98, no. 12, pp. 2714-2719, 1996.

[16] W. Chengya, J. Eshleman, J. Lutterbaugh, B. Y. J. Willson, and S. Markowitz, "Spontaneous apoptosis in human colon tumor cell lines and the relation of wt p53 to apoptosis," Chinese Medical Journal, vol. 109, no. 7, pp. 537-541, 1996.

[17] K. M. Vyas, R. N. Jadeja, D. Patel, R. V. Devkar, and V. K. Gupta, "A new pyrazolone based ternary $\mathrm{Cu}(\mathrm{II})$ complex: synthesis, characterization, crystal structure, DNA binding, protein binding and anti-cancer activity towards A549 human lung carcinoma cells with a minimum cytotoxicity to noncancerous cells," Polyhedron, vol. 65, pp. 262-274, 2013.

[18] X. Yuan, B. Zhang, L. Gan et al., "Involvement of the mitochondrion-dependent and the endoplasmic reticulum stresssignaling pathways in isoliquiritigenin-induced apoptosis of HeLa cell," Biomedical and Environmental Sciences, vol. 26, no. 4, pp. 268-276, 2013.

[19] T. L. Vanden Hoek, C. Li, Z. Shao, P. T. Schumacker, and L. B. Becker, "Significant levels of oxidants are generated by isolated cardiomyocytes during ischemia prior to reperfusion," Journal of Molecular and Cellular Cardiology, vol. 29, no. 9, pp. 25712583, 1997.

[20] J. A. Royall and H. Ischiropoulos, "Evaluation of $2^{\prime}, 7^{\prime}$-dichlorofluorescin and dihydrorhodamine 123 as fluorescent probes 
for intracellular $\mathrm{H}_{2} \mathrm{O}_{2}$ in cultured endothelial cells," Archives of Biochemistry and Biophysics, vol. 302, no. 2, pp. 348-355, 1993.

[21] B.-G. Park, H.-J. Jung, Y.-W. Cho, H.-W. Lim, and C.-J. Lim, "Potentiation of antioxidative and anti-inflammatory properties of cultured wild ginseng root extract through probiotic fermentation," Journal of Pharmacy and Pharmacology, vol. 65, no. 3, pp. 457-464, 2013.

[22] C. Chen, X. Jiang, Y. Hu, and Z. Zhang, "The protective role of resveratrol in the sodium arsenite-induced oxidative damage via modulation of intracellular GSH homeostasis," Biological Trace Element Research, vol. 155, no. 1, pp. 119-131, 2013.

[23] R. J. Vandebriel and W. H. de Jong, "A review of mammalian toxicity of $\mathrm{ZnO}$ nanoparticles," Nanotechnology, Science and Applications, vol. 2012, no. 5, pp. 61-71, 2012.

[24] H. J. Johnston, G. R. Hutchison, F. M. Christensen, S. Peters, S. Hankin, and V. Stone, "Identification of the mechanisms that drive the toxicity of $\mathrm{TiO}_{2}$ particulates: the contribution of physicochemical characteristics," Particle and Fibre Toxicology, vol. 6, article 33, 2009.

[25] A. Jaeger, D. G. Weiss, L. Jonas, and R. Kriehuber, "Oxidative stress-induced cytotoxic and genotoxic effects of nano-sized titanium dioxide particles in human HaCaT keratinocytes," Toxicology, vol. 296, no. 1-3, pp. 27-36, 2012.

[26] B. C. Heng, X. Zhao, E. C. Tan et al., "Evaluation of the cytotoxic and inflammatory potential of differentially shaped zinc oxide nanoparticles," Archives of Toxicology, vol. 85, no. 12, pp. 15171528, 2011.

[27] W. Strober, "Trypan blue exclusion test of cell viability," Current Protocols in Immunology, 2001.

[28] W. Strober, "Wright-Giemsa and nonspecific esterase staining of cells," in Current Protocols in Immunology, appendix 3, appendix 3D, 2001.

[29] J. Monga, S. Pandit, R. S. Chauhan, C. S. Chauhan, S. S. Chauhan, and M. Sharma, "Growth inhibition and apoptosis induction by(+)-cyanidan-3-ol in hepatocellular carcinoma," PLoS ONE, vol. 8, no. 7, Article ID e68710, 2013.

[30] Y. Wang, Y. S. Xu, L. H. Yin et al., "Synergistic anti-glioma effect of Hydroxygenkwanin and Apigenin in vitro," ChemicoBiological Interactions, vol. 206, no. 2, pp. 346-355, 2013.

[31] D. Gao, Z. Xu, P. Qiao et al., "Cadmium induces liver cell apoptosis through caspase-3A activation in purse red common carp (Cyprinus carpio)," PLoS ONE, vol. 8, no. 12, Article ID e83423, 2013.

[32] J. F. Curtin, M. Donovan, and T. G. Cotter, "Regulation and measurement of oxidative stress in apoptosis," Journal of Immunological Methods, vol. 265, no. 1-2, pp. 49-72, 2002.

[33] T. P. Das, S. Suman, and C. Damodaran, "Reactive oxygen species generation inhibits epithelial-mesenchymal transition and promotes growth arrest in prostate cancer cells," Molecular Carcinogenesis, vol. 53, no. 7, pp. 537-547, 2013.

[34] M. J. Akhtar, S. Kumar, H. A. Alhadlaq, S. A. Alrokayan, K. M. Abu-Salah, and M. Ahamed, "Dose-dependent genotoxicity of copper oxide nanoparticles stimulated by reactive oxygen species in human lung epithelial cells," Toxicology and Industrial Health. In press.

[35] K. Donaldson, V. Stone, A. Seaton, and W. MacNee, "Ambient particle inhalation and the cardiovascular system: potential mechanisms," Environmental Health Perspectives, vol. 109, no. 4, pp. 523-527, 2001.

[36] D. M. Townsend, K. D. Tew, and H. Tapiero, "The importance of glutathione in human disease," Biomedicine and Pharmacotherapy, vol. 57, no. 3-4, pp. 145-155, 2003.
[37] S. Catarzi, F. Favilli, C. Romagnoli et al., "Oxidative state and IL-6 production in intestinal myofibroblasts of Crohn's disease patients," Inflammatory Bowel Diseases, vol. 17, no. 8, pp. 16741684, 2011.

[38] M. Ahamed, M. J. Akhtar, M. Raja et al., " $\mathrm{ZnO}$ nanorodinduced apoptosis in human alveolar adenocarcinoma cells via p53, survivin and bax/bcl-2 pathways: role of oxidative stress," Nanomedicine, vol. 7, no. 6, pp. 904-913, 2011.

[39] C. Hanley, J. Layne, A. Punnoose et al., "Preferential killing of cancer cells and activated human $\mathrm{T}$ cells using $\mathrm{ZnO}$ nanoparticles," Nanotechnology, vol. 19, no. 29, Article ID 295103, 2008.

[40] R. Brayner, R. Ferrari-Iliou, N. Brivois, S. Djediat, M. F. Benedetti, and F. Fiévet, "Toxicological impact studies based on Escherichia coli bacteria in ultrafine $\mathrm{ZnO}$ nanoparticles colloidal medium," Nano Letters, vol. 6, no. 4, pp. 866-870, 2006.

[41] M. Premanathan, K. Karthikeyan, K. Jeyasubramanian, and G. Manivannan, "Selective toxicity of $\mathrm{ZnO}$ nanoparticles toward Gram-positive bacteria and cancer cells by apoptosis through lipid peroxidation," Nanomedicine, vol. 7, no. 2, pp. 184-192, 2011. 

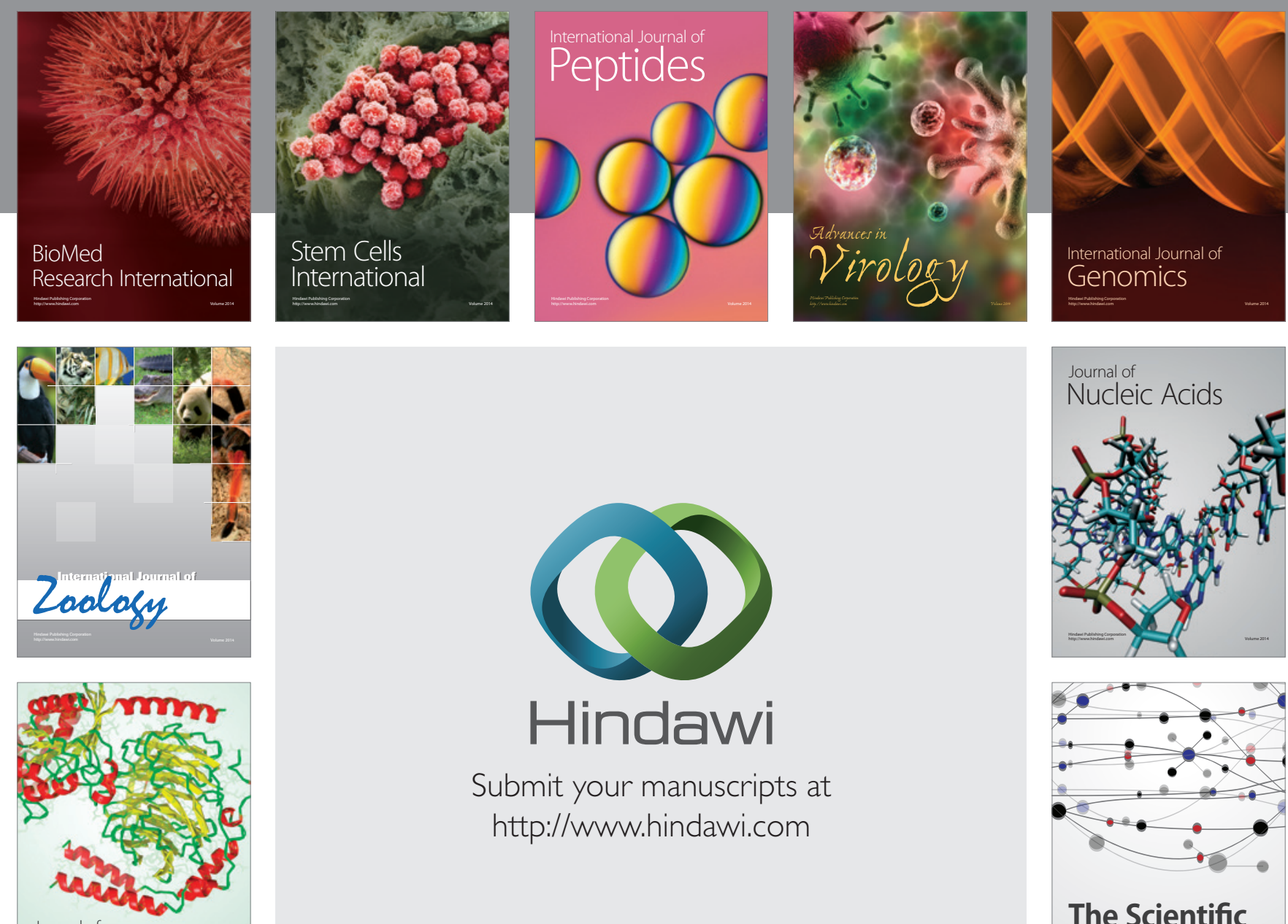

Submit your manuscripts at

http://www.hindawi.com

Journal of
Signal Transduction
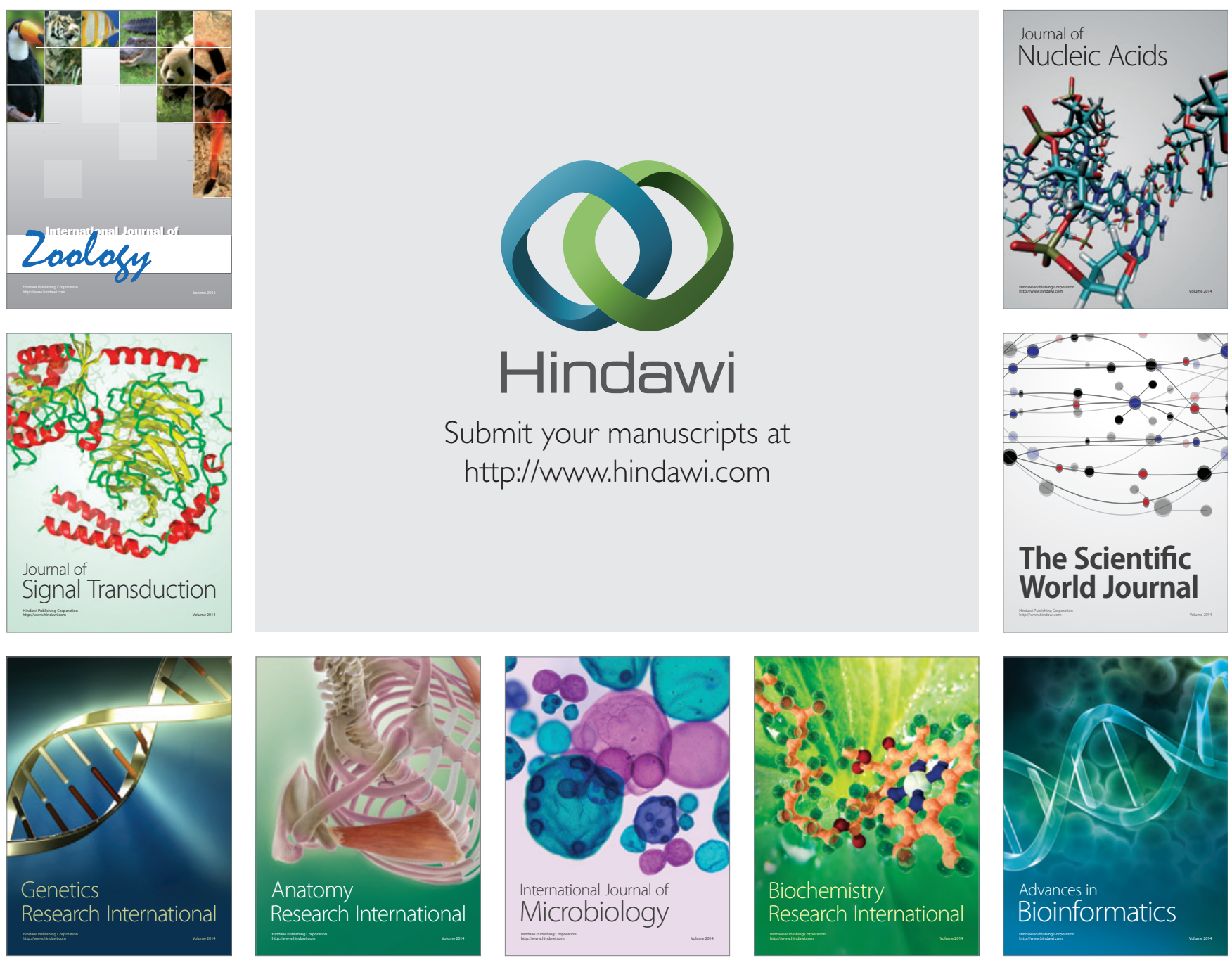

The Scientific World Journal
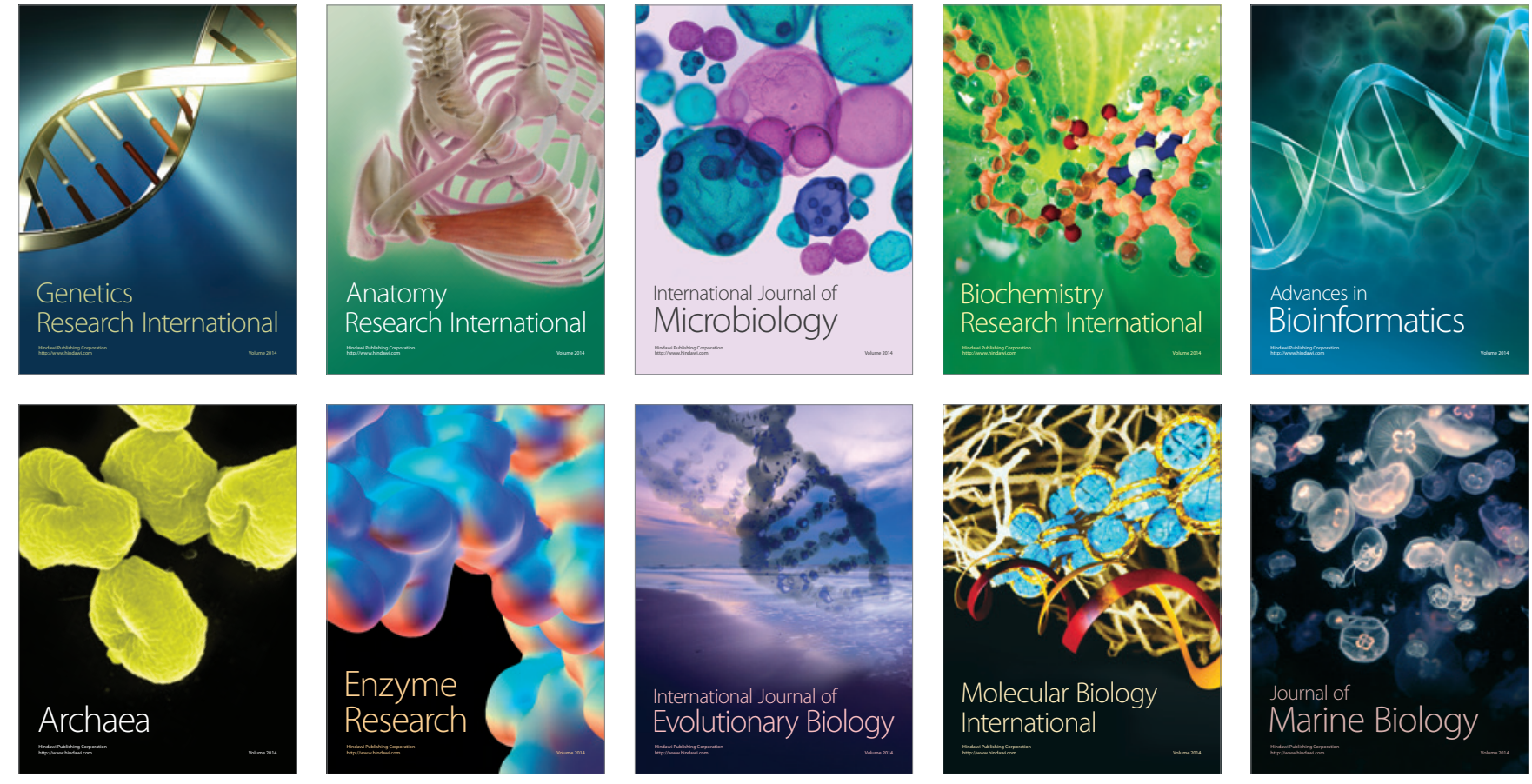